\title{
新型の高効率白液・緑液フィルター
}

カミヤ株式会社 下 川 誠

\section{A New Filter System for White and Green Liquor}

\author{
Makoto Shimokawa \\ Kamyr K. K.
}

A new filter system for filtering of white and green liquor in the chemical recovery system of a kraft pulp mill has been developed.

The system has the advantage of being a continuous process with few mechanical moving parts. The chemical loss with the filtered mud is low, and the closed system prevents oxidation of the liquor.

Based on the pilot plant trail we have done so far, CAUSTEC ${ }^{\mathrm{TM}}$ cassete filter system has demonstrated a remarkable good separation effect of process foreign elements.

Maintenance costs are low and downtime for changing filter elements is only a few hours once or twice a year, providing excellent availability.

\section{1.はじめに}

高品質パルプ生産において高い清澄度の緑液・白液 の重要性はますます高まっている。また，環境要因を 考虑してパルプ工場はクローズド化する方向にあるが， この場合, 薬品ループでの不活性物質の集積が問題に なる。

このような問題を解決するまったく新しいフィル夕 システムがヨタベルケン・エナジー社で開発され、 ヨ タベルンと FL スミスと新しく設立されたCAUSTEC 社で报うことになった。これにともない,この フィルターシステムは CAUSTEC ${ }^{\mathrm{TM}}$ フィルターと名 付けられた。

\section{2. 特徽}

緑液用・白液用ともに構造は同しであり，それぞれ 最適化されたポリプロピレン製のフィルタークロスを 用いている点が両者の間の大きな違いである。

このフィルターシステムの特幑を列挙すると以下の ようになる。

・薬品のロスが少ない

・高い清澄度の万液が得られる

・処理する䳔濁液の状況に左右されにくい

・クロースド化されたシステムでの連繶的な処理か 可能
・コンパクトで可動部分がない

・メンテナンスが容易

・フィルタークロスの洗浄が効果的に行われる

・不活性物質の効果的な除去が可能

これら特徴について以下に具体的に述へる。

\section{1 高い清澄度と少ない薬品ロス}

白液用 CAUSTEC ${ }^{\mathrm{TM}}$ フィルターではスラッシ含有 量 $20 \mathrm{mg} / \mathrm{l}$ 末満のろ液が得られる。また，分離された スラッジ内に含まれる残留ナトリウムはスラッジ1 $\mathrm{kg}$ 当り $30 \mathrm{~g}$ であり, ライムキルン前の石灰泥フィル ターに直接送ることが可能である。

緑液用 CAUSTEC ${ }^{\mathrm{TM}}$ フィルターではろ液中のド レックは含有量 $35 \mathrm{mg} / l$ 末满のろ液が得られ, 分離さ れたドレックの含む残留ナトリウムはドレック $1 \mathrm{~kg}$ 当り $30 \mathrm{~g}$ である。

このように白液・緑夜の両方で高い清澄度と少ない 薬品口スが得られるが,ささらにこの性能はフィルター 入口での愁濁液の状態に左右されないのである。図 1 に緑液の場合のフィルター入口でのドレック含有量と ろ液のドレック含有量の関倸を示すが, 入口でのド レック含有量がろ液の品質に全く関係していないとい える。

また, システム内の空気をコンプレッサで偱環させ， フィルターケーキ中の残留薬液分を置換し薬品口スを 低く抑之ている。 


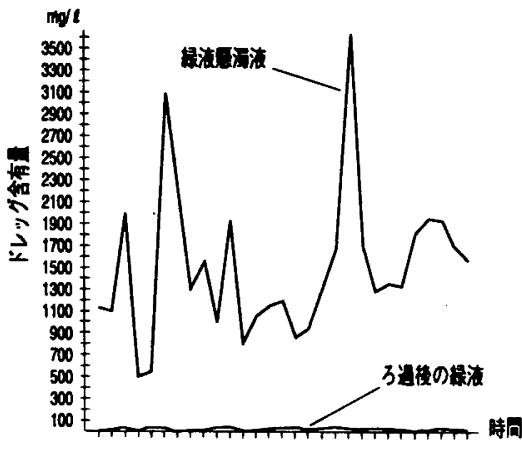

図 1 工場での緑液ろ過テスト

特に白液フィルターでの薬品ロスの減少は, 弱液中 のアルカリ分の再循哧を減少させ, 結果として緑液の 清澄化，スレーキンク，苛性化の各工程での負荷の怪 減をもたらすのである。

\section{2 クローストド化されたシステム}

このフィルターシステムはクロースド化されていて, システム外から空気か供給されることなくシステム内 の空気のみが循罯する。したがって，このシステム内 の空気中に含まれていた酸素が一度酸化反応を起こし 消费されてしまえばこの空気は不活性なガスとなる。 つまり，このフィルターシステム内で白液の酸化反応 は起こらなくなり，硫化度は低下しないのである。

\section{3 不活性物缶の除去}

パルプ工場をクロースド化した場合, プロセスに外 から入る重金属などは回収系に持ち込まれ，エパポ レータでのスケーリンク, 白液生成における石灰泥分 離での問題, 石灰循環での不必要な負荷の発生などか 起こる。

この CAUSTEC ${ }^{\mathrm{TM}}$ フィルタはプロセス上の巽物分 離に対して特筆すべき能力を持っている。

ここに,パイロットプラントで得られた緑液中の重 金属の分離性能を紹介する。

表 1 に示しているのは，3つの工場でのテストの結

表 1 緑液からの金属要素の除去

\begin{tabular}{lrrr}
\hline & $\begin{array}{c}\text { Mill A } \\
\%\end{array}$ & $\begin{array}{c}\text { Mill B } \\
\%\end{array}$ & $\begin{array}{c}\text { Mill C } \\
\%\end{array}$ \\
\hline $\mathrm{Fe}$ & 93 & 89 & 94 \\
$\mathrm{Mg}$ & $>99$ & $>96$ & 97 \\
$\mathrm{Mn}$ & $>92$ & 93 & 94 \\
$\mathrm{Al}$ & 55 & - & 69 \\
$\mathrm{Ba}$ & 21 & 12 & 21 \\
$\mathrm{Zn}$ & - & $>92$ & 91 \\
\hline
\end{tabular}

果である。 $\mathrm{Fe}, \mathrm{Mg}, \mathrm{Mn}, \mathrm{Zn}$ の除去はほほ $90 \%$ 上 得られ，とくにマンガンはほとんど 100\%除去できて いる。

\section{4 フィルタークロスの効果的な洗浄}

フィルタークロスはフィルターエレメントの内側か ら温水によって逆洗されるため，ろ過の際にフィル タークロス上に生成されたフィルターケーキが完全に 取り除かれ，常に高いろ過特性を保つことができる。

\section{5 メンテナンス性}

このフィルターのさらに優れた点としてメンテナン スが容易であることが挙げられる。

具体的には以下のようなことである。

- 可動部品がない。

フィルターエレメント自体は固定されていて動

く部品がなく、故障率が低い。

・スペアパーツがほとんど必要ない。

これは，可動部品がいこともその理由の一つ である。スぺアパーツとして考えられるのは,フィ ルターカートリッジとフィルタークロスぐらいで ある。フィルタークロスはポリプロピレン製のテ クスタイルであり非常に安洒である。

・フィルタークロスの交換は 1 年に 1 回から 2 回で, その際のタウンタイムは 3〜6時間である。

実際のフィルタークロスの交换は，フィルター カートリッジを新しいフィルタークロスを取り付 けたものにまるごと交換することで行う。そのた め,フィルターシステムのタウンタイムは 3 時間 程度で昘む。また，カートリッジに取り付けられ たフィルタークロスそのものの交換はオフライン で行うことができる。

\section{CAUSTEC ${ }^{\mathrm{TM}}$ フィルターの權造・功作}

\subsection{CAUSTEC $^{\mathrm{TM}}$ フィルターの楼造}

CAUSTEC $^{\mathrm{TM}}$ フィルターはフィルターカートリッ ジがれぞれ入った2つのフィルタータンクとその他 の3つのタンク，数台のポンプ，コンプレッサの働き をするナッシュポンプ，バルブなどで構成される。

1つのフィルターエレメントは，ステンレスの波状 板の表面にポリプロピレン製のフィルタークロスを 張ったものであり，1つのフィルターカートリッジは このフィルターエレメント 10 枚程度で構成される。

\subsection{CAUSTEC $^{\mathrm{TM}}$ フィルターの勒作}

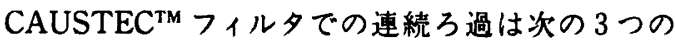
ステップが繰り返されることで行われる。

ステップ 1：㬝濁液のろ過

ステップ 2：フィルターケーキから薬液分除去 
ステップ 3：フィルタークロスの逆洗によるフィル ターケーキの除去, および洗净

\section{ステップ1(国2)}

懸濁液はポンプでフィルタータンクAに供給される。 同時にろ過が開始され，㮣濁液中の固形分はフィル タークロス上にフィルターケーキとして残り，液は フィルタークロスを通り抜けシステム外へ搬送される。 ステップ2 (図3)

フィルタータンク Aへの慜濁液の供給が止まり, フィルタータンク Bへの愻濁液供給が開始される。同 時にフィルタータンク A内に残っていた愳濁液の排出 が開始され、リサーキュレーションタンクを経て, 新 たにシステムに供給される䑨濁液とともにフィルター タンク Bへ送られる。フィルタータンク A内の慗濁液 の排出が終了するとフィルターシステム内の空気をコ ンプレッサで循環させ, 空気がフィルターケーキを通 り抜ける際，フィルターケーキが含む藥液分を置換す

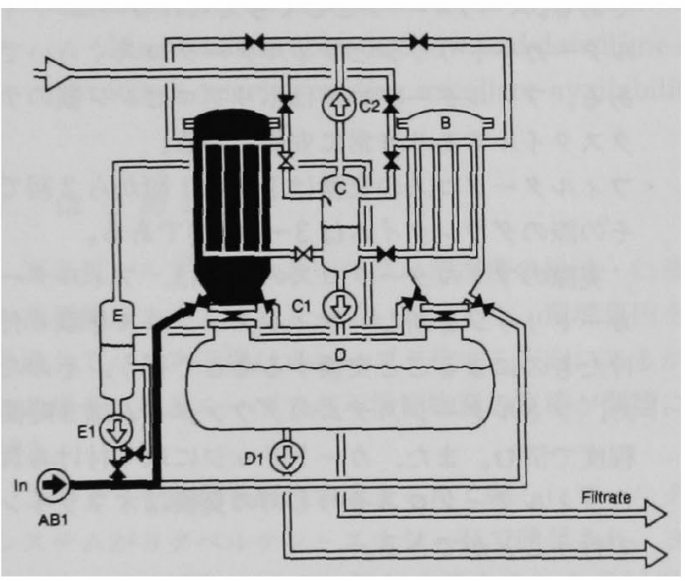

图 2

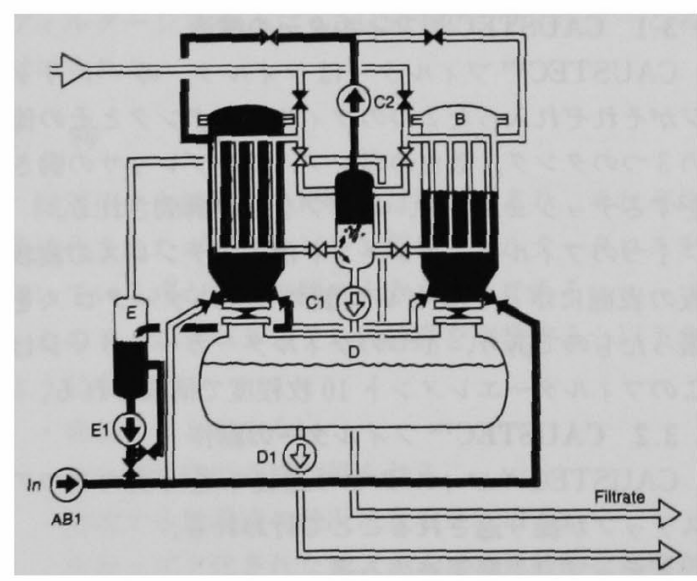

図 3
る。薬液を含んだ空気は分離タンクで空気と薬液に分 けられる。空気に含まれる酸素は一度消費されたら外 部から供給されないので，この空気は不活性なガスと なりろ液を酸化しない。

\section{ステップ 3 (図 4)}

フィルターケーキが含む薬液分の除去後, フィル ターエレメントの内側から蕰水で逆洗が行われ, フィ ルターターキがフィルタークロス上から剝離される。 剝離したフィルターケーキは逆洗で使用した温水と一 緒に下部のタンクに落され, システム外へ搬送される。 以上,これらのステップが図 5 に示すようなシーケ ンスで繰り返される。この困は白液の場合の運転開始 直後のフィルタータンク $\mathrm{A} ・ \mathrm{~B} の$ 状態を示している。常 にどちらかのフィルタータンクでろ過が行われており， 㦟濁液のろ過処理が連続的に行われていることが分か る。

緑液の場合はろ過時間をできるだけ長くとるが（だ いたい 10 分ぐらい)，そのほかのタイミングは白液の 場合とほほ同しになる。

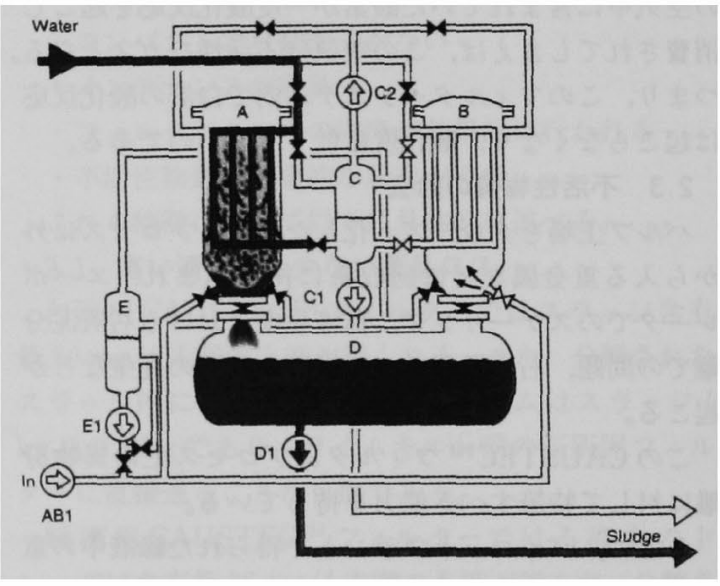

図 4

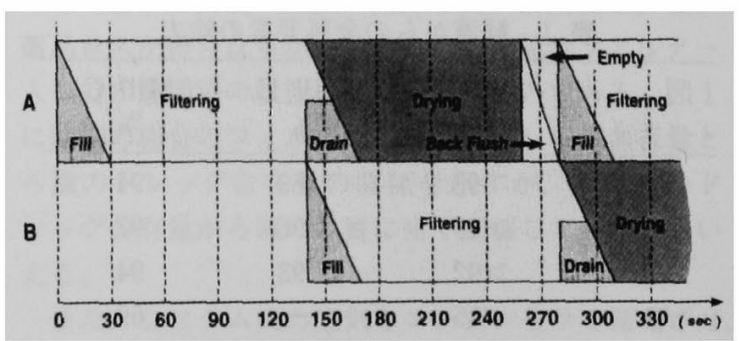

图 5 CAUSTEC $^{\mathrm{TM}}$ Filter Sequence (for White Liquor) 


\section{おわりに}

CAUSTEC $^{\mathrm{TM}}$ フィルターは前述の特徴を持つフィ ルターシステムであるが, 典型的なパルプ工場におい てこのフィルターシステムがもたらす利益は次のよう なものである。

・苛性化工程での能力改善

・マクネシウム, マンガン, 鉄, 亚鉛を $90 \%$ 以上除 去

・ライムキルンでの㜣料消費量を軽減

そして, 現在のパルプ工場での運転上の多くの問題
に対する解決策のみならず，将来パルプ工場をクロー ズド化した場合に発生するであろう問題に対しても解 決策を提供するものである。

\section{参考文献}

Kent Strid and Per Garelius : "A New Filter System for Filtration of Green and White Liquor", TAPPI pulping conference 1992

Rune Hillström : “A New Filter System for White and Green Liquor", Kamyr Götaverken Symposium 1993 